\title{
Van İli Kent Merkezinde Hava Kirliliği
}

\author{
Dilara ÖZTÜRK, Tuba BAYRAM* \\ Van Yüzüncü Yll Üniversitesi, Mühendislik Fakültesi, Çevre Mühendisliği Bölümü, Van \\ (ORCID: 0000-0003-2689-560X) (ORCID: 0000-0003-3282-7099)
}

\begin{abstract}
$\ddot{O} \mathbf{z}$
Cevre kirliliğine neden olan hava kirleticiler ilk sırada insan sağlığı olmak üzere, diğer canlıları ve ekosistemi risk altına sokmaktadır. Ülkemizin birçok kentinde sanayi ve isınmadan kaynaklanan hava kirliliği sorunu önemli boyutlara ulaşmıştır. Bu çalışmada Van ili kent merkezinde hava kirletici parametrelerin zamansal ve mevsimsel dağılımı, konsantrasyonları, kirletici parametrelerin sıcaklık ile ilişkisi izin verilen sınır değerlere göre tartışılmış ve kent için çözüme yönelik önerilere yer verilmiştir. Kentin topoğrafik ve coğrafik konumu itibari ile kış mevsimi sert geçmektedir ayrıca kentin sıcaklık ortalaması ülke geneline göre düşüktür. Bu sebeple 1sınma maksatlı kullanılan yakıtlardan kaynaklı kirleticiler hava kirliliğinde büyük paya sahiptir. Ancak kentin az gelişmiş sanayi şehirlerinden olmasından dolayı endüstriyel menşeili hava kirleticiler kentte çok düşük konsantrasyonlarda bulunmaktadır. Isınma amaçlı düşük enerjili ve yüksek kükürt içeren kömür türevlerinin sık kullanımı ve yanlış yakma teknikleri kış aylarında görülen yoğun kirliliğin sebebini ortaya koymaktadır. Bu sebeple doğal gaz gibi daha temiz yakıtların kullanımı bu sorun için en uygun çözümlerden biridir. Kentin doğal gaz ulaşmayan ilçelerine hat sağlanması ile tehlikesiz ve temiz bir yakıt olarak kabul görülen doğal gazın kullanılmasının yaygınlaştırılması gerekmektedir. Ayrıca hattın ulaşmadığı noktalarda kalitesiz yakıt konusunda kontroller satış noktalarından başlayıp kullanıcılar bilgilendirilmeli ve zararları izah edilmelidir.
\end{abstract}

Anahtar kelimeler: Hava Kirliliği, Van, Fosil Yakıtlar, Doğal gaz.

\section{Air Pollution in the City Center of Van Province}

\begin{abstract}
Air pollutants that cause environmental pollution put human beings and other ecosystems at risk. In many cities of our country, the problem of air pollution caused by industrial and heating has reached significant levels. In this study, the temporal and seasonal distribution of air pollutant parameters in the city center of Van province, its concentrations, and the relation of pollutant parameters with temperature are discussed according to the permissible limit values and recommendations for solution for the city are included. The winter season is harsh in terms of topographic and geographic location of the city and the average temperature of the city is lower than the country average. Therefore, pollutants from the fuels used for heating purposes have a large share in air pollution. However, industrial pollutants of industrial origin are found in very low concentrations in the city due to the fact that the city is one of the less developed industrial cities. Frequent use of low-energy high-sulfur coal derivatives for heating purposes and incorrect combustion techniques reveal the reason for the heavy pollution seen in the winter months. Therefore, the use of cleaner fuels such as natural gas is one of the most suitable solutions for this problem. With the provision of lines to the districts that do not reach the natural gas, the use of natural gas, which is considered as a safe and clean fuel, should be expanded. Furthermore, at the points where the line does not reach, the controls on the poor-quality fuel should be started from the sales points and the users should be informed and their losses should be explained.
\end{abstract}

Keywords: Air Pollution, Van, Fossil Fuels, Natural gas.

*Sorumlu yazar: tubabayram@yyu.edu.tr

Geliş Tarihi: 19.02.2019, Kabul Tarihi: 01.07.2019 


\section{Giriş}

Doğa, insanlık için en büyük ekonomik kaynak olmakla beraber tüm canlılar için tek sığınaktır. Biyolojik soykırımın devam etmesi halinde ekolojik denge bozulacağından, en büyük tehlike ve risk yine insanlığa olacaktır. Nüfus artışının büyük bir ivme kazandığı bu dönemde dünyanın her metrekaresi artarak değer kazanırken, nihayeti düşünülmeden kirletilen yerküre için gerekli önlemler alınmaz ise, 22. yüzyılın başlangıcından itibaren insanlığı zor günlerin beklediği gerçeği kabul edilmelidir. Kırsal alanlarda yerleşimin azalmasıyla ülke içi göçlerin artarak sürdügü, dünya nüfusunun \%48'inin büyük illerde toplandığı bir ortamda, ekolojinin sağlıklı döngüsü için yapılması gereken ilk girişim, hükümetlerin alacağı tedbirlerdir. Fiziksel olarak milyonlarca yılın yükünü taşıyan dünyada, insanlar da savaşlar ve ekonomik sıkıntılarla mücadele etmekten yorgun düşmüş durumdadır. İnsanlar, sosyal refaha erişebilmek ve ekonomik güçlükler ile baş edebilmek için doğayı ve doğal kaynakları hesapsızca yok etmek riskini göz ardı edip, doğaya hâkimiyetlerini kanıtlamak istercesine sahip oldukları teknolojiyle sağlıklı ve çevre dostu üretim yaptıklarına inanmakla, aslında doğaya geri dönüşü olmayan yollarla zarar vermektedirler.

Ekolojik ve ekonomik kalkınmanın sağlanması ve sürdürülmesi için küresel boyutta sermaye girişimlerine ve nüfus dengesinin ve ekolojik dengenin bozulmaması, endüstri ve çevre entegrasyonunun sağlıklı bir çerçevede olması gerekmektedir.

Değişen zamana eş olarak gelişen dünyada endüstrileşmenin getirdiği en mühim problemlerden birisi de çevre kirliliğidir. 20. yüzyılın ikinci yarısına kadar bu konuyu göz ardı eden insanoğlu, çevreye egemenliğini sağladığını sandığı anda ekolojik açıdan doğanın negatif tepkisi ile karşılaşmıştır. Bugün dünya gündemini işgal eden bu problemin çözümü için yalnız gelişmiş ülkeler değil, aynı zamanda gelişmekte olan ülkeler de bazı ekonomik, teknik ve hukuki tedbirler alma mecburiyeti duymaktadırlar [1]. Genel olarak günümüzün çevre sorunları artan üretim ve tüketimin dişa vurmuş bir sonucu olarak görülebilir. Şüphesiz bu durum, yerkürenin doğal varlıklarını yok etme hakkını insanoğluna vermemektedir. Ekosistemi korumak amacı ile gelişmeye başlayan bu yeni bilincin bir neticesi olarak, birçok ülke ekolojik sorunların ehemmiyetini kavrayıp çözümü hususunda araştırma yapabilecek kuruluşlar oluşturarak kendi çevre politikalarını belirlemeye başlamışlardır, hatta bazı ülkeler bu doğrultudaki çalışmalarını tamamlamışlardır. Öte yandan hem insanların hem kirlilik kaynaklarının hem de kirlenmeyi oluşturan öğeleri taşıyan hava, toprak ve su gibi alıcı ortamların hareketliliği, kirlenme konusundaki yaklaşımların sadece ulusal değil aynı zamanda global açıdan da ele alınmasını gerekli kılmış ve çevre kirlenmesi hususundaki hassasiyete uluslararası, hatta uluslar üstü bir vasıf kazandırmıştır [2].

Çevre kirliliği; canlı türlerinin yok olması, doğal kaynakların tükenmesi, üçüncü dünya ülkelerinde açlık ve batı ülkeleri için de yaşamın zorlaşmasıyla eş anlamlıdır [3]. Çevreci eylem geçici bir heves, bir akım veya üstünlük malzemesi olmaktan çıkarılıp, bir yaşam felsefesi haline getirilmediği sürece çevre kirliliğinin ve bu durumla bağlantılı olarak dünyadaki ekolojik dengenin bozulmasının engellenmesi mümkün olmayacaktır [4].

Hava kirliliği çevre kirliliğinde başı çeken sorunlarından biridir. Hava, kimyasal kompozisyonu sebebiyle tüm canlıların ve insanlığın yaşamsal faaliyetinin devamı için hayatidir. Hava kirliliği atmosferde gaz, duman, toz, su buharı formunda bulunabilecek olan kirleticilerin tüm canlı ve cansız varlıklara zarar verici miktar ve konsantrasyonlarda artması olarak tanımlanabilir. İnsanların türlü faaliyetleri sonucunda ortaya çıkan üretim ve tüketim aktiviteleri esnasında ve sonrasında meydana çıkan atıklar ile atmosfer tabakası kirletilerek ekolojideki tüm canlı hayat olumsuz etkilenmektedir. Hava kirleticilerin atmosfere deşarj edildiği yere ya da faaliyete kaynak denilmektedir. Kirlilik kaynağı; doğal orman yangınları, yanardağ püskürmesi gibi doğal kaynaklar, evsel ısınma faaliyetleri, endüstri kuruluşları, motorlu araçlar gibi yapay kaynaklar şeklindedir [5]. Hava kirliliğinin boyutları özellikle sanayinin hızlı gelişmesi, hızlı nüfus artışı ve evsel kaynaklı fosil yakıtların kullanılması ile artmıştır. $\mathrm{Bu}$ çalışmada Van ili kent merkezinde hava kirletici parametrelerin zamansal ve mevsimsel dağılımı, konsantrasyonları, kirletici parametrelerin sıcaklık ile ilişkisi incelenerek kentin hava kirliliği ile ilgili sorunları için çözüme yönelik önerilere yer verilmesi amaçlanmıştır. 


\section{Materyal ve Metot}

Çalışmanın yapılmasında, daha önce kamu kuruluş ve kurumlarında yapılmış durum raporları ve çalışmalara dayalı istatistikî verilerden yararlanılmıştır. Çalışmanın objektif açıdan değerlendirilebilmesi için elde edilen bilgilerin doğruluğu kıyaslamalı olarak tartışılmıştır. Çalışmanın sürdürülebilirliği ve uygulanabilirliği için geçerli olan yönetmelik ve kanunların uygulanma şekilleri incelenmiştir.

\subsection{Doğal gaz}

Doğal gaz, fosil kaynaklı bir çeşit yanıcı gaz karışımı olan bir petrol türevidir. Yakıt olarak ehemmiyet sıralamasında ham petrolden sonra ikinci sırayı alır. Yer kabukları arasındaki fosil atıklar, sıcaklık ve basıncın etkisiyle, kimyasal değişikliklere uğrayarak oluşmuşlardır. Dünyada bilinmekte olan doğal gaz rezervleri yaklaşık $1014 \mathrm{~m}^{3}$ olup, en yüksek pay eski Sovyetler Birliği'nde olup oran \%35'tir, Sovyetler Birliği'ni takiben \%34'lük bir oranla Orta Doğu yer almaktadır. Türkiye'de tüketime sunulan yıllık doğal gaz miktarı bugün için yaklaşı 16 milyar $\mathrm{m}^{3}$ olup, bu kapasitenin yeni hatlar ile imzalanan muahedeler ile artması beklenmektedir. Doğal gazın Türkiye'de az bulunması sebebi ile doğal gazı Rusya ve İran'dan boru hatlarıyla, Cezayir ve Nijerya'dan ise sıvılaştırılmış biçimde deniz yoluyla temin etmekteyiz. Buna ek olarak Türkmenistan ve Azerbaycan ile doğal gaz tedarik etmek için uzlaşma sağlanmıştır [6].

Doğal gaz genellikle karbon, gaz halindeki parafin ve hidrojen bileşimden oluşur ve bulunma oranları da gazın çıkış kaynağına göre değişmektedir. Doğal gaz yüksek oranda metan $\left(\mathrm{CH}_{4}\right)$ ve düşük oranda propan $\left(\mathrm{C}_{3} \mathrm{H}_{8}\right)$ ve etan $\left(\mathrm{C}_{2} \mathrm{H}_{6}\right)$ gibi hidrokarbonlardan oluşur. Ek olarak yapisında azot $\left(\mathrm{N}_{2}\right)$, karbondioksit $\left(\mathrm{CO}_{2}\right)$, hidrojen sülfür $\left(\mathrm{H}_{2} \mathrm{~S}\right)$ ve helyum $(\mathrm{He})$ gazları da bulunabilmektedir. Doğal gaz renksiz, kokusuz ve ekonomik bir kaynaktır, bilhassa yoğuşmalı kombiler ile kullanıldığı zaman diğer yakıt türlerine kıyasla en az \%10 yakıt ekonomisi imkânı sağlar. Ayrıca, yakıt hazırlama, depolama, temizlik ve kül atma maliyetleri dikkate alınırsa, işletme maliyetlerinde önemli kazanımlar sağladığı söylenebilir. Kömür veya fuel-oil kullanılması durumunda kazan yüzeylerinde toplanan kurum ve kül katmanı yüzeylerde aşınmaya sebep olurken diğer yandan 1sı geçişini zorlayarak kazan veriminin düşmesine sebep olmaktadır. Bu sebeple kazanlar periyodik olarak temizlenmek durumundadır. Fakat doğal gaz kullanıldığında bu tür bir sorun ile karşılaşılmamaktadır [7]. Doğal gazın 1sıtmada kullanımında diğer yakıtlarla karşılaştırılması Tablo 1'de verilmiştir [8].

Tablo 1. Isınma amaçlı kullanılan doğal gazın diğer yakıtlarla kıyaslanması [8]

\begin{tabular}{cccc}
\hline Bileşim & Kömür & Fuel-oil & Doğal gaz \\
\hline Karbon (\%) & 77,4 & 84,58 & 73,98 \\
Hidrojen (\%) & 1,4 & 10,90 & 24,57 \\
Kükürt (\%) & 1,0 & 4,00 & - \\
Kül (\%) & 8,0 & - & - \\
Nem (\%) & 7,0 & - & \\
Isıl değer [kj/kg (kcal/kg)] & $29.600(7.080)$ & $39.220(9.380)$ & $49.085(11.780)$ \\
Baca gazındaki SO konsantrasyonu (ppm) $_{2}$ & 1.644 & 5,5 & - \\
Hava fazlalığı & $1,4-2,0$ & $1,2-1,3$ & $1,05-1,1$ \\
\hline
\end{tabular}

Doğal gazın en olumlu yönlerinden biri de zehirsiz olmasıdır. Solunması durumunda öldürücü ve zehirleyici etkisi olmamakla birlikte ortamda çok fazla birikim olmuş ise solunacak oksijen azaldığ1 için boğulma tehlikesi yaratır. Yanma sonucu çıkan gazlar ortama yayılırsa, diğer yakıtlarda olduğu gibi içerisindeki CO nedeniyle zehirleme yapabilmektedir [9].

Çevre Kanunu'na dayanarak 1986 yılında 2872 sayılı Hava Kalitesinin Kontrolü Yönetmeliği (HKKY) hazırlanmıştır. Daha sonra bu yönetmelik 13.01.2005 tarih ve 25699 sayılı 'Isınmadan Kaynaklanan Hava Kirliliği Yönetmeliği' olarak değişmiştir. Bu yönetmelik çeşitli faaliyetler sonucunda havaya dağılan duman, is, gaz, toz, aerosol ve buhar formundaki emisyonları kontrol altına almak, insanı ve çevresini içinde bulunduğu bu kirletici ortamdan dolayı oluşabilecek tehlikelerden korumak, çevreye zararlar veren olumsuz etkilerini azaltmak ve olabildiğince engellemek amacı ile 
Çevre Kanunu hükümleri gereğince çıkarılmıştır. Yönetmelik; amaç, tanım, hedef sınır değerler, hava kalitesi limit değerleri, kirleticilerin tespiti ve ölçümü ile ilgili usuller, tesisler için emisyon sınırları gibi hava kirliliği ile ilgili bilgileri içermektedir. Uluslararası ülkeler ve kuruluşlarca yapılmış çalışmalar nihayetinde hava kirliliğini meydana getiren kirleticilerin insan sağlığını kötü şekilde etkilemeyecek 'güvenirlilik sınır değerleri' tespit çalışmaları yürütülmüş ve bu verilere 'standart limit değerler' adı verilmiştir [10]. Aynı şekilde Hava Kalitesinin Korunması Yönetmeliği’nde de farklı kaynaklardan atmosfere salınabilecek kirleticilere yönelik sınır değerler belirtilmiştir. Hava kirliliğinin genellikle kış mevsiminde belli bölgelerimizde uyarı sınırlarını aşması kirlenmenin insan yaşamını tehdit edebilecek hudutlara geldiğini işaret etmektedir. Hava kirlenmesinin önlenebilmesi için yönetmelikte kısa ve uzun dönemde uygulanabilecek tedbirler yer almaktadır [11].

\subsection{Hava kalitesi yönetimi ve yasal yükümlülük}

Hava Kalitesi Yönetmeliği'nin maksadı; çeşitli faaliyetler sonucunda atmosfere dağılan toz, duman, buhar, is, aerosol ve gaz formundaki emisyonları kontrol altına almak; insanı ve yaşadığı çevreyi hava alıcı ortamındaki kirleticiler sebebiyle olası risklerden korumak; hava kirlenmeleri nedeniyle oluşan halka ve komşuluk ilişkilerine ciddi zararlar veren negatif etkileri azaltmak, uzaklaştırmak ve bu etkilerin ortaya çıkmasını engellemektir.

Ülkemizde bilhassa 1sınma maksat11, kükürt oranı yüksek kalorisi düşük kömürlerin yaygın kullanımı ve yakma tekniklerinin yanlış tatbik edilmesi hava kirliliğine neden olmaktadır. Nüfus çoğalması ve ekonomik düzeyin yükselmesiyle, sayısı gitgide artan motorlu araçlardan salınan egzoz gazları, hava kirliliğinde büyük bir paya sahiptir.

Endüstrilerin kuruluşunda yer seçiminin yanlış yapılması, çevre korunması bakımından zorunlu önlemlerin alınmaması (baca filtresi olmaması vb.), uygun ve çevreci teknolojilerin uygulanmaması, yakma tesislerinde kalitesiz, düşük kalorili ve kükürt oranı yüksek yakıtların kullanılması hava kirliliğine neden olan etmenlerin başında gelmektedir.

Ulusal hava kalitesi indeksinde (HKI) karbon monoksit (CO), partikül maddeler $\left(\mathrm{PM}_{10}\right)$, azot dioksit $\left(\mathrm{NO}_{2}\right)$, ozon $\left(\mathrm{O}_{3}\right)$ ve kükürt dioksit $\left(\mathrm{SO}_{2}\right)$ ve olmak üzere 5 ana kirletici için hava kalitesi indeksi hesaplanmaktadır. HKI'nin değerlendirilebilmesi açısından kirleticilerin indekste belirtilen kategorilere karşılık gelen yoğunlaşma aralıkları Tablo 2'de verilmiştir.

Tablo 2. Hava kalitesi ile ilişkili olarak hava kalite indeksinin (HKİ) karşılaştırılması [12].

\begin{tabular}{|c|c|c|c|c|c|c|}
\hline \multirow{2}{*}{ İndeks } & \multirow{2}{*}{ HKİ } & $\mathrm{SO}_{2}\left[\mu \mathrm{g} / \mathrm{m}^{3}\right]$ & $\mathrm{NO}_{2}\left[\mu \mathrm{g} / \mathrm{m}^{3}\right]$ & $\mathrm{CO}\left[\mu \mathrm{g} / \mathrm{m}^{3}\right]$ & $O_{3}\left[\mu \mathrm{g} / \mathrm{m}^{3}\right]$ & $\mathrm{PM}_{10}\left[\mu \mathrm{g} / \mathrm{m}^{3}\right]$ \\
\hline & & 1 Sa. Ort. & 1 Sa. Ort. & 8 Sa. Ort. & 8 Sa. Ort. & 24 Sa. Ort. \\
\hline İyi & $0-50$ & $0-100$ & $0-100$ & $0-5.500$ & $0-120^{\mathrm{L}}$ & $0-50$ \\
\hline Orta & $51-100$ & $101-250$ & $101-200$ & $5.501-10.000$ & $121-160$ & $51-100^{\mathrm{L}}$ \\
\hline Hassas & $101-150$ & $251-500^{\mathrm{L}}$ & $201-500$ & $10.001-16.000^{\mathrm{L}}$ & $161-180^{\mathrm{B}}$ & $101-260^{\mathrm{U}}$ \\
\hline Sağlıksız & $151-200$ & $501-850^{\mathrm{U}}$ & $501-1.000$ & $16.001-24.000$ & $181-240^{\mathrm{U}}$ & $261-400^{\mathrm{U}}$ \\
\hline Kötü & $201-300$ & $851-1.100^{\mathrm{U}}$ & $1.001-2.000$ & $24.001-32.000$ & $241-700$ & $401-520^{\mathrm{U}}$ \\
\hline Tehlikeli & $301-500$ & $>1.101$ & $>2.001$ & $>32.001$ & $>701$ & $>521$ \\
\hline
\end{tabular}

$\mathrm{SO}_{2}$ ve PM için Dünya Sağlık Örgütü'ne (WHO) ve Hava Kalitesinin Korunmas1 Yönetmeliği'ne göre belirlenen limit değerler Tablo 3'te verilmiştir.

Tablo 3. Hava Kalitesinin Korunması Yönetmeliği ve $\mathrm{WHO}^{\text {'ya göre } \mathrm{SO}_{2} \text { ve } \mathrm{PM} \text { için belirlenen sınır değerler [12] }}$

\begin{tabular}{|c|c|c|c|}
\hline \multicolumn{2}{|c|}{ Standart Değerler } & $\mathrm{SO}_{2}\left(\mu \mathrm{g} / \mathrm{m}^{3}\right)$ & $\mathbf{P M}\left(\mu \mathrm{g} / \mathrm{m}^{3}\right)$ \\
\hline \multicolumn{2}{|c|}{ WHO'ya göre } & UVSD. $=150$ & UVSD. $=75$ \\
\hline \multicolumn{2}{|c|}{ Hava Kalitesinin Korunma Yönetmeliğine göre } & 250 & 200 \\
\hline \multirow{4}{*}{ Uyarı Kademeleri } & 1. Uyarı Kademesi & 700 & 400 \\
\hline & 2. Uyarı Kademesi & 1.100 & 600 \\
\hline & 3. Uyarı Kademesi & 1.500 & 800 \\
\hline & 4. Uyarı Kademesi & 2.000 & 1.000 \\
\hline
\end{tabular}

*UVSD: Uzun vadeli sınır değer 
Tablo 3’teki $\mathrm{SO}_{2}$ ve $\mathrm{PM}$ için verilen sınır değerler göz önüne alındığında $\left(\mathrm{SO}_{2}-\mathrm{PM}\right.$ için sırasıyla; 250-200 $\mu \mathrm{g} / \mathrm{m}^{3}$ )' dir. Bu çalışma ile Van'da ölçülen $\mathrm{SO}_{2}$ ve PM değerlerinin Hava Kalitesinin Korunmas1 Yönetmeliği sınır değerleri ile birlikte değerlendirilecektir.

Motorlu kara taşıtlarının kullanımları sırasında çıkan emisyonlar Sanayi ve Ticaret Bakanlı̆̆ 1 tarafınca belirlenen limit değerlerin altında tutulur. Araçların emisyonlarının azaltılması maksadı ile taşıtların yapısı ve ekipmanlarıyla ilgili esaslar Sanayi ve Ticaret Bakanlığı'nca yürürlüğe konulan araçların imal, tadil ve montajı hakkındaki yönetmelikte belirtilir. Araçların teknik muayenesi ile ilgili usuller ise kara araçları için Bayındırlık ve İskân Bakanlığı, karayolları genel müdürlüğü, su taşıtları ve demiryolu için ise Ulaştırma Bakanlığı tarafından Başbakanlık Çevre Genel Müdürlügü ile koordinasyon içinde belirlenir. Motorlu kara araçlarının egzoz gazındaki hava kirleticiler için emisyon sınır değerleri TSE (Türk Standartları Enstitüsü) 4236'da belirlenen limitleri aşmamalıdır. TSE'de standardı bulunmayan durumlarda ise, konu ile ilgili TSE tarafindan ilgili standartlar düzenlenip yürürlüğe geçinceye kadar AET (Avrupa Ekonomik Topluluğu) standartlarındaki sınırlar esas alınır. Diğer taraftan hava kalitesinin kritik değerlere varması durumunda veya hava akımlarının az olduğu yerlerde valilikler sürekli veya geçici olarak trafiği durdurabilir ve/veya kısıtlayabilir.

\section{Bulgular ve Tartışma}

Van ilinde Çevre ve Şehircilik Bakanlığı'na ait bir tane hava izleme tesisi mevcuttur. Bu istasyonda başlıca kirleticiler olan $\mathrm{SO}_{2}$ ve $\mathrm{PM}_{10}$ değerleri takip edilmektedir. İzlenen veriler temel alınarak Van ilinde 2016 ile 2019 yılları arasında temiz hava eylem planı düzenlenmiştir. Bu eylem planına ek olarak sıvı yakıt ve kömür ile alakalı her sene il mahalli çevre kurulunda satıcılar ve tüketiciler için kıstaslar belirlenmektedir. Van ilinin ülkenin doğusunda yer alması ve sert hava koşulları sebebiyle kış mevsiminde ısınma için fazlaca yakıt kullanılmaktadır bu sebeple kış sezonu süresince de yakıt kontrolleri yapılmaktadır.

\subsection{Yakit türü}

Van ilinde evsel 1sıtma için 2007 yılı öncesinde çoğunlukla kömür, 2007 y1lından beri ise doğal gaz ile kömür kullanılmaktadır, odun, LPG, fuel-oil ve benzeri yakıtların kullanımı yok denecek kadar azdır. 2016 yılında evsel ısınma amaçlı kullanılan yakıtlara ait özellikler Tablo 4’te verilmiştir.

Tablo 4. 2016 yılında evsel ısınma amaçlı kullanılan yakıtlara ait özellikler [12]

\begin{tabular}{cccccccc}
\hline Cinsi & Menşei & $\begin{array}{c}\text { Tüketim miktarı } \\
\text { (ton) }\end{array}$ & $\begin{array}{c}\text { Alt Isıl Değer } \\
(\mathbf{k c a l} / \mathbf{k g})\end{array}$ & $\begin{array}{c}\text { Uçucu } \\
\text { Madde (\%) }\end{array}$ & $\begin{array}{c}\text { Kükürt } \\
(\boldsymbol{\%})\end{array}$ & $\begin{array}{c}\text { Nem } \\
(\%)\end{array}$ & $\begin{array}{c}\text { Kül } \\
(\%)\end{array}$ \\
\hline Kömür & İthal & 740.000 & 6.400 & $12-31$ & 0,9 & 10 & 16 \\
Kömür & Yerli & 250.000 & 4.200 & - & 2,3 & 30 & 30 \\
Doğal gaz & İthal & $49.020 .566,4$ & 8.250 & - & - & - \\
\hline
\end{tabular}

Binalarda sıcak su ihtiyacı, ocak ve ısınma maksatlı tüketilen doğal gaz il genelinde (İpekyolu, Tuşba ve Edremit ilçeleri) 2016 yılı sonundan itibaren $82.793 .628,450 \mathrm{Sm}^{3} / \mathrm{y} 1 \mathrm{l}$ olup kentin \% 61'i doğal gaz kullanır durumdadır (Tablo 5). Edremit, İpekyolu ve Tuşba ilçeleri dışındaki ilçelerde doğal gaz hattının henüz ulaştırılamamış olmasından dolayı bu rakamlar kent çoğunluğu için geçerli olmaktadır.

Tablo 5. Van ilinde 2016 yılında kullanılan doğal gaz miktarı [13]

\begin{tabular}{ccc}
\hline Kullanıldığı Mekân & Tüketim Miktarı $\left(\mathbf{S m}^{\mathbf{3}}\right)$ & Isıl Değer $\mathbf{( k c a l / \mathbf { k g } )}$ \\
\hline Ev & $49.020 .566,46$ & $9.006,12$ \\
Ticarethane & $10.474 .261,19$ & $9.006,12$ \\
Resmi Kurum & $19.608 .487,37$ & $9.006,12$ \\
Endüstri & $3.398 .589,86$ & $9.006,12$ \\
Diğer & $291.723,57$ & $9.006,12$ \\
\hline
\end{tabular}


Doğal Piyasası 2016 yılı sektör raporundan temin edilen bilgilerine göre [13]; Aksa Van Doğal Gaz A.Ş' nin abone sayısı konutlarda 45.339, ticarethanede 4.624, resmi dairede 1.239, ibadethane, vakıf, hayır kurumun da 237, organize sanayi sitesinde 28 adet olarak belirtilmiştir. İl genelinde doğal gaz abone sayısı toplamda 51.467 adettir. 2016 yılında konut 1sıtılması maksadı ile kullanılan kömür tüketim miktarı ise yaklaşık olarak 990.000 tondur.

Van ili endüstri açısından gelişmediği için endüstriyel emisyonlardan kaynaklı kirlilik oldukça azdır. Van ilinde 17 adet emisyon izni almış endüstriyel yapı bulunmaktadır. Hava kirliliği sadece endüstriyel ve evsel kaynaklı değil aynı zamanda ulaşım faaliyetleri sonucu da oluşmaktadır. Endüstride kullanılan yakıtların türü, temin edildiği yerlerle ilgili veriler ve özellikleri Tablo 6'da verilmiştir.

Tablo 6. 2016 yılında endüstriyel alanlarda kullanılan katı yakıtlara ait özellikler [12]

\begin{tabular}{cccccccc} 
& & & \multicolumn{4}{c}{ Yakıtın Özellikleri } \\
\cline { 3 - 7 } $\begin{array}{c}\text { Yakıtın } \\
\text { Cinsi }\end{array}$ & $\begin{array}{c}\text { Temin Edildiği } \\
\text { Yer }\end{array}$ & Tüketim Miktarı & $\begin{array}{c}\text { Alt Isıl } \\
\text { Değeri } \\
(\mathrm{kcal} / \mathrm{kg})\end{array}$ & $\begin{array}{c}\text { Uçucu } \\
\text { Madde } \\
(\%)\end{array}$ & $\begin{array}{c}\text { Toplam } \\
\text { Kükürt } \\
(\%)\end{array}$ & $\begin{array}{c}\text { Toplam } \\
\text { Nem } \\
(\%)\end{array}$ & $\begin{array}{c}\text { Kül } \\
(\%)\end{array}$ \\
\hline Kömür & İthal & $43.370($ ton $)$ & 6.400 & $12-31$ & 0,9 & 10 & 16 \\
Doğal gaz & İthal & $3.398 .589,86\left(\mathrm{Sm}^{3}\right)$ & 8.250 & - & - & - & - \\
\hline
\end{tabular}

2011 yılında Devlet Planlama Teşkilatı tarafinca yapılan ve 8 alt başlıkta 61 endeksin incelendiği bölge ve kentlerin sosyal ve ekonomik gelişmişlik sıralaması araştırması (SEGE) endeks araştırmasında Van 75. sıradadır [14]. Toplam sanayi işletmeleri arasında \%0,1'lik oran ile Van, endüstriyel açıdan az gelişmiş kentlerdendir.

2015 'te gerçekleştirilen Van kentinin sanayi envanterinin oluşturulması fizibilite çalışmasında [15] Van'da ki sanayi kuruluşu sayısının 240 olduğu belirlenmiştir. Van ilindeki sanayi kuruluşlarından 72 tanesi Van-Erciş karayolundaki Van organize ve sanayi bölgesi'nde yer almaktadır [15].

Kullanılan yakıtın türünün hareketli araçlardaki kompozisyonuda oldukça önemlidir. Hava Kalitesi Değerlendirme ve Yönetimi Yönetmeliği'ne göre kişiler motorlu araçlarını düzenli bir şekilde egzoz gazı emisyon testine tabi tutmak zorundadırlar. Bu düzenli testler Çevre ve Şehircilik Bakanlığı tarafından yetki alan egzoz gazı emisyon ölçüm tesisleri tarafınca gerçekleştirilmektedir. Van ilinde 2016 yılı içerisinde egzoz gazı emisyon testi yapılan araç sayısı 55.768'dir [12]. Hava Kalitesi Değerlendirme ve Yönetimi Yönetmeliği'ne göre kentin hava kalitesine ulaşım kaynaklı emisyonların $\left(\mathrm{O}_{3}, \mathrm{NO}_{2}, \mathrm{SO}_{2}, \mathrm{CO}, \mathrm{PM}\right)$ etkisi orta düzeyde $\left(50-100 \mu \mathrm{g} / \mathrm{m}^{3}\right)$ iken sanayi kaynaklı emisyonların $\left(\mathrm{NO}_{2}\right.$, $\left.\mathrm{SO}_{2}, \mathrm{CO}_{2}, \mathrm{PM}\right)$ etkisi ise çok düşük $\left(0-50 \mu \mathrm{g} / \mathrm{m}^{3}\right)$ seviyededir. Bu kirleticilerin en etkin, zararlı ve yoğun olanlar1 egzoz gazında bulunan $\mathrm{CO}, \mathrm{HC}, \mathrm{NO}_{\mathrm{X}}$ ve $\mathrm{PM}$ (is duman vb.) olup bunlardan $\mathrm{NO}_{\mathrm{X}}$ ve $\mathrm{PM}$ emisyonları daha çok dizel motorlarından kaynaklanmaktadır

\subsection{Hava kalitesi kontrolü hususundaki çalışmalar}

Çevre ve Şehircilik Bakanlı̆̆g'nca 18 Ekim 2005 tarihinde Van ilinde kurulan ve hâlen faaliyet gösteren bir adet hava kalitesi izleme tesisi yer almaktadır. Tesis, yaklaşık 600.000 dolaylarında bir nüfusa denk gelen 3 mühim yerleşim yerinin (İpekyolu, Tuşba ve Edremit İlçeleri) merkezinde yer almaktadır. Yerleşim yerlerine yakın olması nedeniyle ısınma kaynaklı hava kirliliğinin, taşıt yoluna yakın olması nedeni ile de ulaşım kaynaklı kirliliğinin ölçülmesi bakımından çok makul bir noktada yer alsa da bilhassa 1sınmadan kaynaklı hava kirliliğinin ölçülmesi açısından dezavantajlı bir tesistir. Çünkü ölçüm tesisinin bulunduğu yerde daha tehlikesiz bir yakıt türü olan doğal gaz kullanılmaktadır. Bu durumda diğer yakıt türlerinin kullanıldığı yerleşkelerdeki kirliliği tam olarak yansıtmamasına sebep olmaktadır. Ancak bazı bölgelerde ve 2011 yılında meydana gelen Van depreminden sonra inşa edilen toplu konutlar nedeniyle kalabalık bir yerleşim mahali olan Edremit'te doğal gaz hattı çekilmemiş olup kömür kullanılmaktadır. Edremit TOKİ konutlarının ölçüm tesisine mesafesi ise 15 km'dir. Mevcut ölçüm tesisinin endüstri menşeili kirleticilerin bulunduğu tesislere mesafesi $10 \mathrm{~km}$ 'dir. Diğer taraftan rüzgâr hızı düşük $(1,5 \mathrm{~m} / \mathrm{s})$ olup partiküler maddelerin rüzgâr ile taşınımı az olduğu için hava kirliliğinin yerel yoğunlaşması söz konusudur [12]. Dolayısıyla iklim koşulları, kent nüfusu, 1sınma amaçlı kullanılan yakıtın karakteristiği ve endüstrinin dağılımı göz önüne alındığında, tek istasyondan alınan verilerin, 
kentin bütününü temsil etmesi açısından yetersiz olmaktadır. Bu sebeple, var olan tesise ek olarak Edremit ilçesinde, sanayi bölgesinde ve diğer gerekli görülen (nüfusu çok olan Erciş ilçesi gibi) ilçelerde de tesis kurulması gerektiği düşünülmektedir. Van ilinde bulunan hava kalitesi ölçüm tesisinde, partikül madde $\left(\mathrm{PM}_{10}\right)$ ve kükürt dioksit $\left(\mathrm{SO}_{2}\right)$ ölçülmektedir bu parametrelerin günlük ortalama değerleri 2016 yılı için sırası ile Şekil 1 ve Şekil 2'de verilmiştir. Ayrıca 2016 yılına ait $\mathrm{SO}_{2}$ ve $\mathrm{PM}_{10}$ konsantrasyonları ay bazında Tablo 7'de verilmiştir.

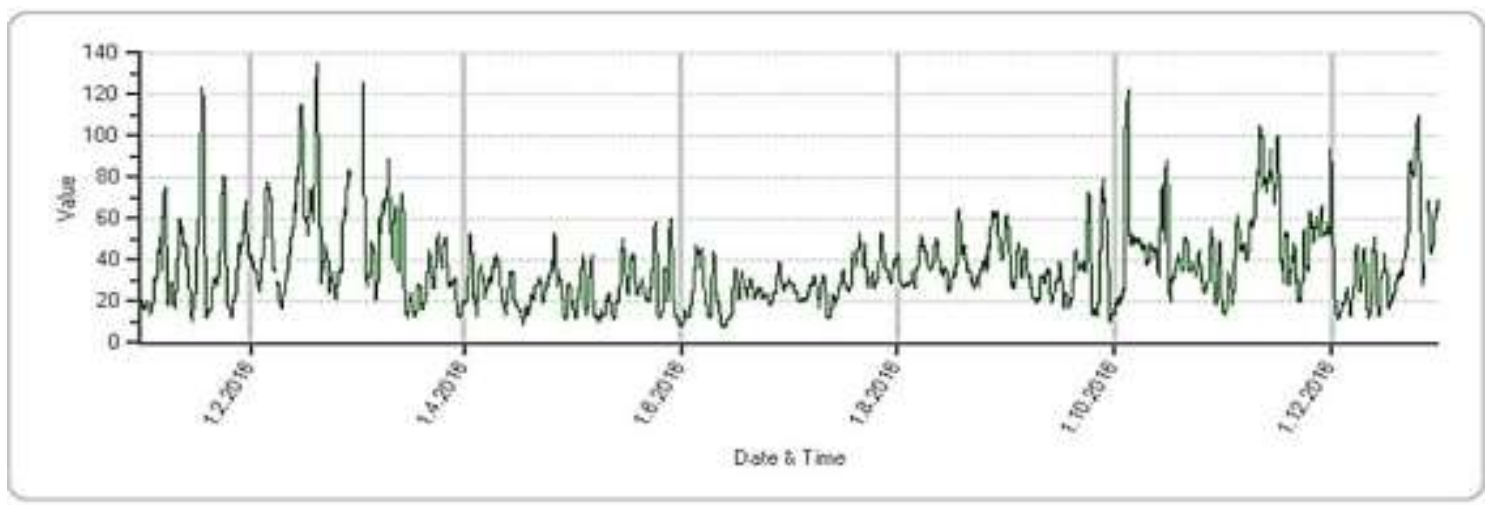

PM10[ug/min'

Şekil 1. 2016 yılı günlük ortalama $\mathrm{PM}_{10}$ parametresi değerleri [12]

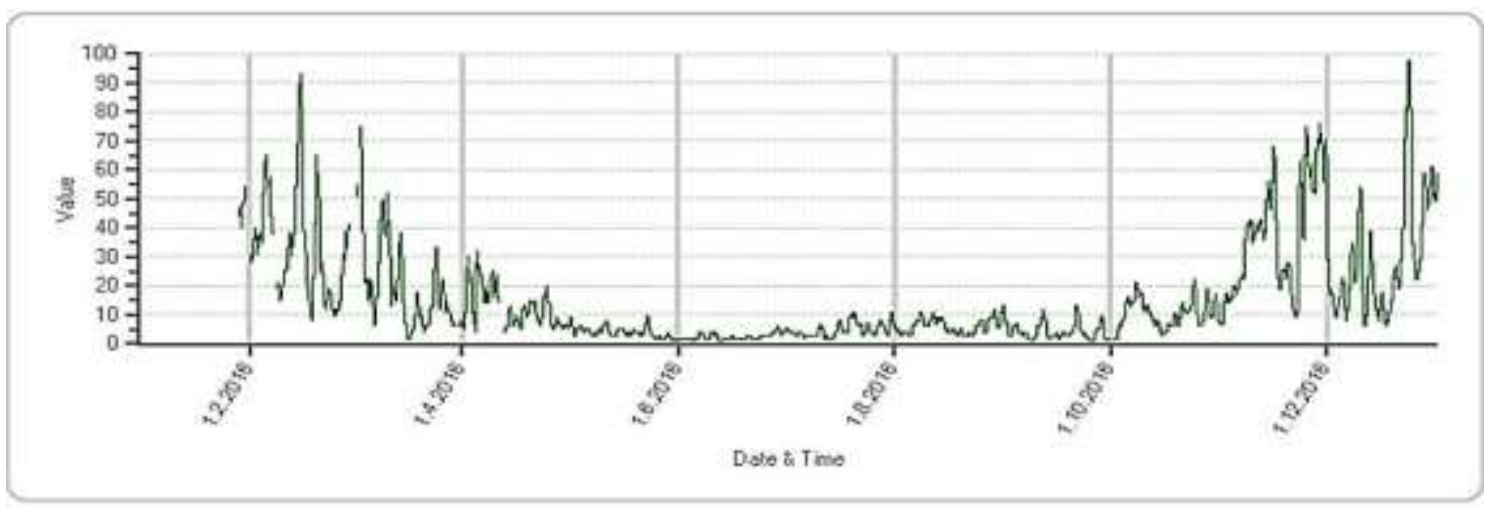

Şekil 2. 2016 y1lı günlük ortalama $\mathrm{SO}_{2}$ parametresi değerleri [12]

Çalışma kapsamında Van il Çevre ve Şehircilik Müdürlüğü’nden alınan veriler derlenerek 2016 yılına ait Van ili hava kirliliği profili çıkarılmıştır. Şekil 1 ve 2'de görüldüğü gibi birbirini takip eden günlerde $\mathrm{PM}_{10}$ ve $\mathrm{SO}_{2}$ değerlerinde ani değişimler olduğu görülmektedir. Şekil 1'de kış aylarında artan ani $\mathrm{PM}_{10}$ konsantrasyonları o günlerde hava sıcaklığının diğer günlere nazaran daha soğuk olması ile bağıntılı olarak halen fosil yakıt kullanarak ısınan konutlardan salınan emisyonlara bağlı olarak arttığ düşünülmektedir. Aynı şekilde 1.2.2016 ile 1.4.2016 tarihleri arasında azalan $\mathrm{SO}_{2}$ konsantrasyonu havanın ısınmaya başlaması ile birlikte konut ssınmasında azalan fosil yakıt kullanımı ile ilgilidir, diğer taraftan 1.10.2016 ile 1.12.2016 tarihleri arasında günlük $\mathrm{SO}_{2}$ konsantrasyonundaki artış kentin coğrafik ve iklimsel koşulları sebebiyle kış aylarının erken başlayıp sert geçmesi ile ilişkilidir dolayısı ile bu aylarda 1sınma maksatlı tercih edilen fosil yakitların daha fazla kullanımı ile $\mathrm{SO}_{2}$ konsantrasyonları artmıştır. Ayrıca 2016 yılı şubat ayı içerisinde birbirini takip eden günlerde $\mathrm{SO}_{2}$ konsantrasyonunda dalgalanma olduğu Şekil 2'de görülmektedir. Bu durum Meteoroloji Genel Müdürlüğ̈̈'nce sunulan rapora [16] göre Doğu Anadolu bölgesinin 2016 yılı şubat ayı ortalama sıcaklığının diğer yıllara göre normallerinin üzerinde olması ve yaşanan sıcaklık dalgalanmaları ile açıklanabilir. Şubat ayı içerisinde birbirini takip eden günlerde yaşanan sıcaklık farkları sebebiyle bir gün çok soğuk diğer gün güneşli ve daha 1lık geçtiği için ısınma kaynaklı yakıt kullanımının miktarı da bu duruma paralel olarak değişmiştir, bu durum da $\mathrm{SO}_{2}$ ve $\mathrm{PM}_{10}$ derişimlerinin bir gün çok diğer gün daha az olmasına sebep olmuş ve ölçümlere yansımıştır. 
Genel olarak kentin hava sıcaklığı ekim ayının sonlarından itibaren düşmeye başlar ve takip eden, kasım, aralık, ocak, şubat aylarında sert, mart ve nisan aylarında yavaş yavaş isınmaya başlar. Nisan ayından sonra azalan $\mathrm{PM}_{10}$ ve $\mathrm{SO}_{2}$ konsantrasyonlarının bu durum ile ilişkili olduğu düşünülmektedir. Ancak 2016 yılı kış mevsiminde ölçülen $\mathrm{SO}_{2}$ ve $\mathrm{PM}_{10}$ değerlerinin önceki y1llara göre az olmasına rağmen yine de yüksek olduğu görülmektedir. Bu durum doğal gaz şebeke hattının kentinin her yerine ulaşmaması ve doğal gaz hattının ulaştığı yerlerde ise doğal gaz kullanımının gerekliliklerinin (kombi, kalorifer, tesisat döşenmesi vb.) karşılanamaması sebebiyle fosil yakıt kullanımının devam etmesi ile ilişkilidir.

Tablo 7. $\mathrm{SO}_{2}$ ve $\mathrm{PM}_{10} 2016$ y1lı aylik ortalamalar1 [17]

\begin{tabular}{ccc}
\hline Ay & $\mathbf{S O}_{\mathbf{2}}\left(\mu \mathrm{g} / \mathrm{m}^{\mathbf{3}}\right)$ & $\mathbf{P M}_{\mathbf{1 0}}\left(\boldsymbol{\mu g} / \mathbf{m}^{\mathbf{3}}\right)$ \\
\hline Ocak & 47 & 38 \\
Şubat & 34 & 52 \\
Mart & 19 & 38 \\
Nisan & 13 & 27 \\
Mayis & 4 & 25 \\
Haziran & 3 & 24 \\
Temmuz & 5 & 30 \\
Ağustos & 6 & 40 \\
Eylül & 4 & 32 \\
Ekim & 11 & 42 \\
Kasım & 38 & 55 \\
Aralık & 31 & 41 \\
ORTALAMA & $\mathbf{1 5}$ & $\mathbf{3 7}$ \\
\hline
\end{tabular}

Hava kalitesi ölçüm istasyonu tarafından 2014-2016 yıllarında ölçülen $\mathrm{PM}_{10}$ ve $\mathrm{SO}_{2}$ değerlerinin hava kalitesi sınır değerleri aşım verileri ise Tablo 8'de listelenmiştir. Bu tesisin haricinde Van kentinde ulusal hava izleme ağından bağımsız başka bir tesis mevcut değildir.

Tablo 8. 2014- 2016 yılları arasındaki hava kalitesi sınır değerleri aşım durumu [12]

\begin{tabular}{|c|c|c|c|c|c|}
\hline \multicolumn{2}{|c|}{2014} & \multicolumn{2}{|c|}{2015} & \multicolumn{2}{|c|}{2016} \\
\hline $\mathbf{P M}_{10}$ & $\mathrm{SO}_{2}$ & $\mathbf{P M}_{10}$ & $\mathrm{SO}_{2}$ & $\mathbf{P M}_{10}$ & $\mathrm{SO}_{2}$ \\
\hline \multicolumn{2}{|c|}{ KVS } & \multicolumn{2}{|c|}{ KVS } & \multicolumn{2}{|c|}{ KVS } \\
\hline $100 \mu \mathrm{g} / \mathrm{m}^{3}$ & $250 \mu \mathrm{g} / \mathrm{m}^{3}$ & $90 \mu \mathrm{g} / \mathrm{m}^{3}$ & $225 \mu \mathrm{g} / \mathrm{m}^{3}$ & $80 \mu \mathrm{g} / \mathrm{m}^{3}$ & $200 \mu \mathrm{g} / \mathrm{m}^{3}$ \\
\hline $103(09.01 .2014)$ & & $127(14.01 .2015)$ & & $94(17.01 .2016)$ & \\
\hline 109 (10.01.2014) & & $106(15.01 .2015)$ & & $98(14.02 .2016)$ & \\
\hline 100 (11.01.2014) & & $99(19.01 .2015)$ & & $87(15.02 .2016)$ & \\
\hline $110(12.01 .2014)$ & & $92(20.01 .2015)$ & & $84(18.02 .2016)$ & \\
\hline 107 (17.01.2014) & & $113(21.01 .2015)$ & & $111(19.02 .2016)$ & \\
\hline $140(20.01 .2014)$ & & $90(22.01 .2015)$ & & $98(03.10 .2016)$ & \\
\hline $126(22.01 .2014)$ & & $101(25.01 .2015)$ & & 105 (10.11.2016) & \\
\hline $110(13.02 .2014)$ & & $107(26.01 .2015)$ & & $86(13.11 .2016)$ & \\
\hline $124(14.02 .2014)$ & & $93(27.01 .2015)$ & & $96(15.11 .2016)$ & \\
\hline $112(15.02 .2014)$ & & $103(03.02 .2015)$ & & $81(30.11 .2016)$ & \\
\hline $114(20.02 .2014)$ & & $92(07.02 .2015)$ & & $82(22.12 .2016)$ & \\
\hline $111(21.02 .2014)$ & & $140(12.02 .2015)$ & & $80(23.12 .2016)$ & \\
\hline $116(22.02 .2014)$ & & $101(07.03 .2015)$ & & $103(24.12 .2016)$ & \\
\hline $110(23.02 .2014)$ & & $106(08.03 .2015)$ & & 97 (31.12.2016) & \\
\hline $140(24.02 .2014)$ & & $100(04.10 .2015)$ & & & \\
\hline 20 gün & $\begin{array}{l}\text { Sinır değer } \\
\text { aşılmamıştır. }\end{array}$ & 16 gün & $\begin{array}{l}\text { Sinır değer } \\
\text { aşılmamıştır. }\end{array}$ & 14 gün & $\begin{array}{l}\text { Sinır değer } \\
\text { aşılmamıştır. }\end{array}$ \\
\hline
\end{tabular}

*KVS: Kısa vadeli sınır değer 
Tablo 8'de 2014 ile 2016 y1l arasında ölçülen günlük ortalama $\mathrm{PM}_{10}$ ve $\mathrm{SO}_{2}$ konsantrasyonlarının izin verilen günlük değerleri aşıp aşmadığı gösterilmiştir. Bu yıllardaki ölçüm süresince $\mathrm{SO}_{2}$ değeri aşılmamış, $\mathrm{PM}_{10}$ verilerinde ise 2014'te 20 gün, 2015'te 16 gün ve 2016 yılında ise 14 gün limit aşımı görülmüştür. Limit değerlerin aşıldığı noktalar göz önüne alındığında aşım tarihlerinin kış aylarına denk geldiği ve her geçen yıl düşüş gösterdiği açıktır. Hava kalitesi izleme verilerinin yıllık ortalamasının Hava Kalitesi Değerlendirme ve Yönetimi Yönetmeliği’nde [18] belirlenen limit değerlerle kıyaslamalı gösterimi ise Şekil 3'te verilmiştir.

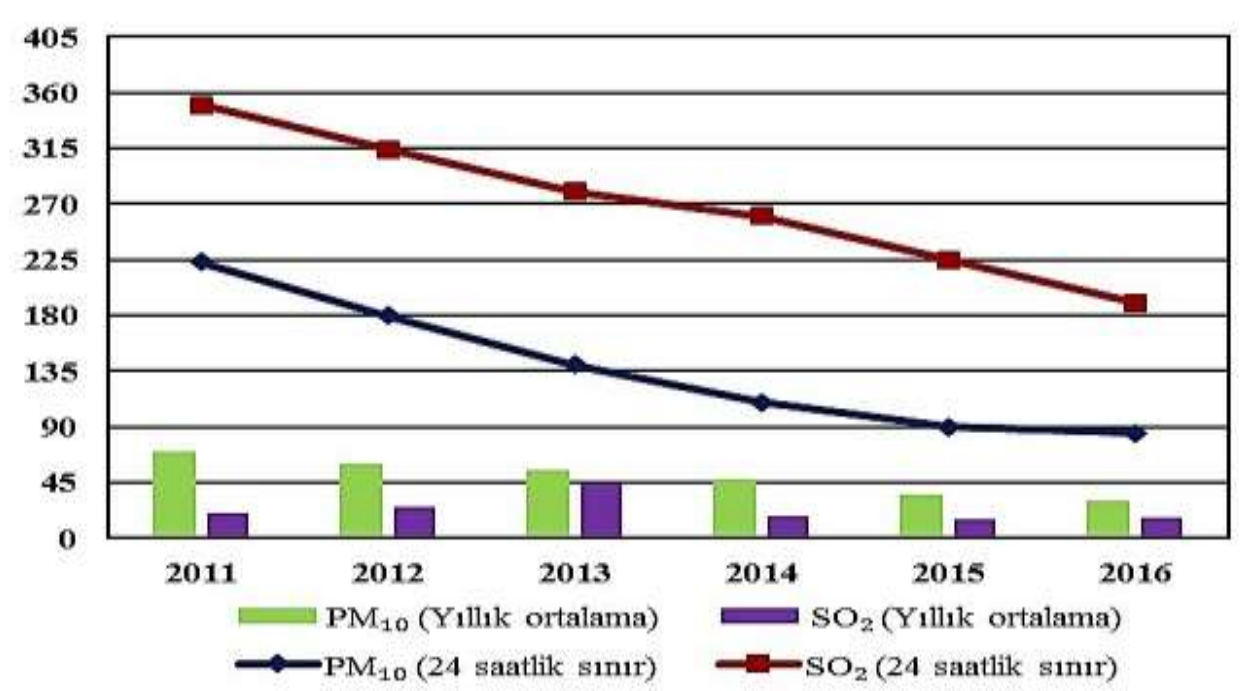

Şekil 3. Hava kalitesi parametrelerinin yıllık ortalamasının sınır değerlerle karşılaştırmalı olarak gösterimi [12]

Ayrıca Şekil 3'te Van ilinde 2011 y1lında $\mathrm{SO}_{2}$ ve $\mathrm{PM}_{10}$ konsantrasyonları sınır değerlerle kıyaslandığında çok yüksek olduğu ancak 2014 y1lı itibariyle yıllık ortalama $\mathrm{SO}_{2}$ ve $\mathrm{PM}_{10}$ konsantrasyonunun sınır değerlere yakınlık göstermeye başladığı görülmektedir. Bunun sebebinin de ilde doğal gaz kullanımının artmaya başlaması olduğu düşünülmektedir.

6 yıllık (2010-2016) veriler değerlendirildiğinde $\mathrm{SO}_{2}$ ve $\mathrm{PM}_{10}$ konsantrasyonlarının kentte mevsimsel olarak artış gösterdiği gözlemlenmiştir. Tablo 9'da yıllara göre kış dönemi hava kalitesi izleme verilerinin ortalaması gösterilmektedir.

Tablo 9'dan da görüleceği üzere 2010 ile 2016 yılları arasında ortalama $\mathrm{PM}_{10}$ ve $\mathrm{SO}_{2}$ konsantrasyonlarının, ölçüm süresince $\mathrm{SO}_{2}$ konsantrasyonunun 2010-2013 yılları arasında önce azaldığı, 2012-2013 yılları arasında arttığ 1 ve daha sonra düşüş gösterdiği, 2016 yıllık ortalamasının ise $18 \mu \mathrm{g} / \mathrm{m}^{3}$ olduğu görülmektedir. $\mathrm{PM}_{10}$ konsantrasyonlarının ise 2010-2016 aralığında genel olarak azalma eğiliminde olduğu ve 2016 yılındaki ortalamasının ise $37 \mu \mathrm{g} / \mathrm{m}^{3}$ olduğu açıktır. Şekil 4 'te 2016 y1lına ait kaydedilen $\mathrm{PM}_{10}$ ve $\mathrm{SO}_{2}$ konsantrasyonları ile aylık sıcaklık verilerinin ortalama değerleri verilmiştir.

Şekil 4'te $\mathrm{SO}_{2}$ ve sıcaklık değerleri arasındaki ters ilişki dikkat çekmektedir. Bu durum hava sıcaklığının yüksek olduğu zamanlarda 1sınma ihtiyacının olmaması ya da az olması sebebiyle azalan yakıt kullanımı ile açıklanabilir. Dolayısıyla bu durum kentte $\mathrm{SO}_{2}$ kirliliğinin çoğunlukla 1sınmadan kaynaklı olduğuna işaret etmektedir. Ayrıca $\mathrm{PM}_{10}$ konsantrasyonu en yüksek kış aylarında görülürken ağustos ayında bir miktar artış göstermiştir. Bu duruma sebep olarak $\mathrm{PM}_{10}$ 'un doğal kaynakları (artan sicaklıkla topraktan atmosfere karışan PM'ler, denizler, bataklıklar vb.) gösterebilir.

Şekil 5'te kentte mevcut doğal gaz şebeke hattının haritası yer almaktadır. Kentte Avrupa, WHO ve Amerika Birleşik Devletleri (ABD) sınır değerlerinin üstünde seyreden $\mathrm{SO}_{2}$ konsantrasyonları yakıt stratejisindeki değişmeyle WHO ve ABD sınır değerlerinin altına düşmüştür.

Şekil 5'ten de görüleceği üzere kent merkezine doğal gaz hattı genel olarak ulaşmış olup uzak ilçelerde doğal gaz hattı çekim işlemleri başlatılmıştır [13]. Önümüzdeki birkaç yıl içerisinde kentin tamamına doğal gaz hattının ulaşması öngörülmektedir. 
Tablo 9. Yıllara göre kış dönemi hava kalitesi izleme verileri ortalamaları $(2010$ - 2016) [12]

\begin{tabular}{|c|c|c|c|c|c|c|c|c|c|c|c|c|}
\hline \multirow[b]{2}{*}{ YIL } & \multicolumn{2}{|c|}{ EKİM } & \multicolumn{2}{|c|}{ KASIM } & \multicolumn{2}{|c|}{ ARALIK } & \multicolumn{2}{|c|}{ OCAK } & \multicolumn{2}{|c|}{ ŞUBAT } & \multicolumn{2}{|c|}{ MART } \\
\hline & $\begin{array}{c}\mathbf{P M}_{10} \\
\left(\mu \mathrm{g} / \mathbf{m}^{3}\right)\end{array}$ & $\underset{\left(\mu \mathrm{g} / \mathbf{m}^{3}\right)}{\mathbf{S O}_{2}}$ & $\underset{\left(\mu \mathrm{g} / \mathbf{m}^{3}\right)}{\mathbf{P M}_{\mathbf{3}}}$ & $\underset{\left(\mu \mathrm{g} / \mathbf{m}^{3}\right)}{\mathbf{S O}_{2}}$ & $\underset{\left(\mu \mathrm{g} / \mathbf{m}^{3}\right)}{\mathbf{P M}_{10}}$ & $\underset{\left(\mu \mathrm{g} / \mathbf{m}^{3}\right)}{\mathbf{S O}_{2}}$ & $\underset{\left(\mu \mathrm{g} / \mathbf{m}^{3}\right)}{\mathbf{P M}_{\mathbf{3}}}$ & $\underset{\left(\mu \mathrm{g} / \mathbf{m}^{3}\right)}{\mathbf{S O}_{2}}$ & $\underset{\left(\mu \mathrm{g} / \mathbf{m}^{3}\right)}{\mathbf{P M}_{10}}$ & $\underset{\left(\mu \mathrm{g} / \mathbf{m}^{3}\right)}{\mathrm{SO}_{2}}$ & $\underset{\left(\mu \mathrm{g} / \mathbf{m}^{3}\right)}{\mathbf{P M}_{10}}$ & $\underset{\left(\mu \mathrm{g} / \mathbf{m}^{3}\right)}{\mathbf{S O}_{2}}$ \\
\hline $\begin{array}{r}2010 \\
-2011\end{array}$ & 109 & 10 & 156 & 90 & 142 & 101 & 80 & 63 & 53 & 30 & 94 & 31 \\
\hline $\begin{array}{l}2011 \\
-2012\end{array}$ & 84 & 7 & 57 & 10 & 78 & 24 & 41 & 42 & 38 & 54 & 56 & 40 \\
\hline $\begin{array}{c}2012 \\
-2013\end{array}$ & 75 & 4 & 62 & 17 & 72 & 60 & 72 & 135 & 76 & 111 & 73 & 45 \\
\hline $\begin{array}{r}2013 \\
-2014\end{array}$ & 58 & 20 & 62 & 44 & 79 & 112 & 74 & 86 & 77 & 54 & 60 & 23 \\
\hline $\begin{array}{r}2014 \\
-2015\end{array}$ & 35 & 2 & 47 & 3 & 59 & 29 & 65 & 31 & 58 & 23 & 46 & 20 \\
\hline $\begin{array}{l}2015 \\
-2016\end{array}$ & 28 & 4 & 36 & 13 & 48 & 20 & 38 & 47 & 52 & 34 & 38 & 19 \\
\hline
\end{tabular}

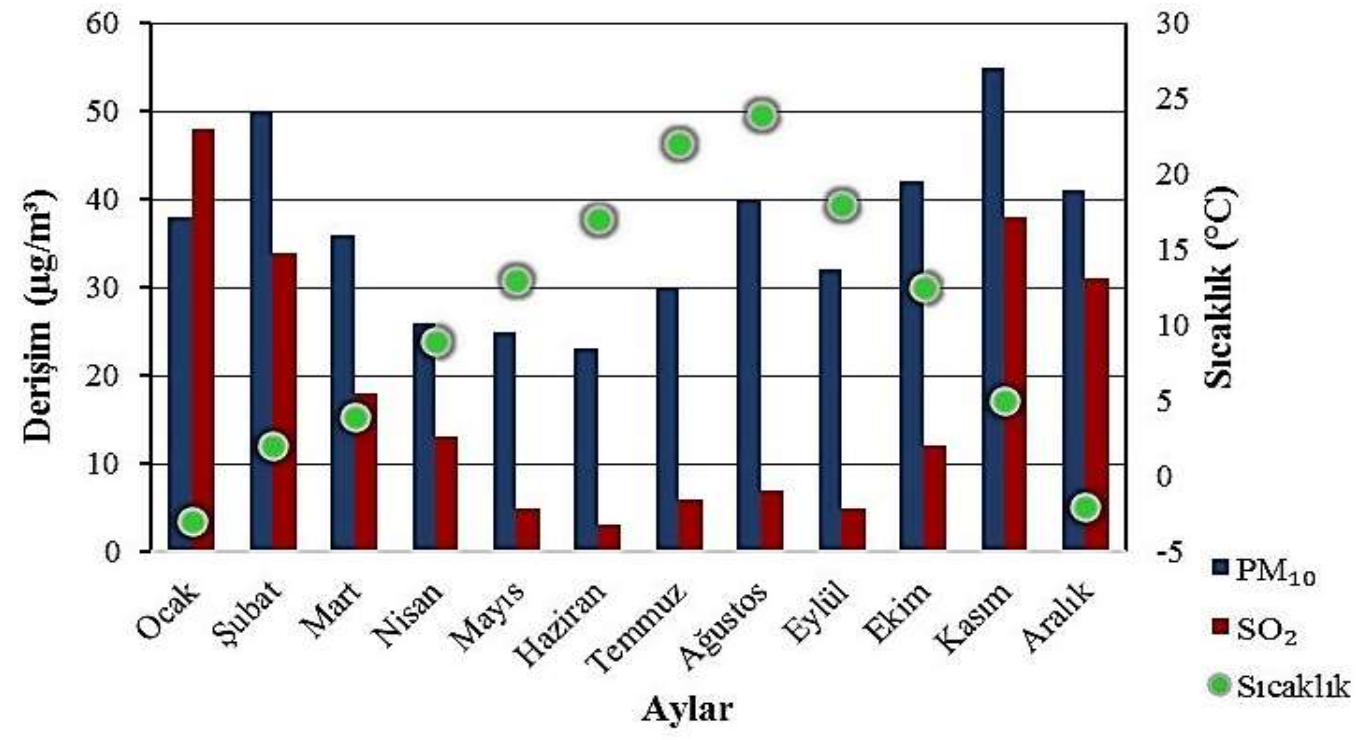

Şekil 4. 2016 yılı $\mathrm{PM}_{10}-\mathrm{SO}_{2}$ derişimlerinin aylık ortalamaları ve sıcaklık ile ilişkisi [12] 


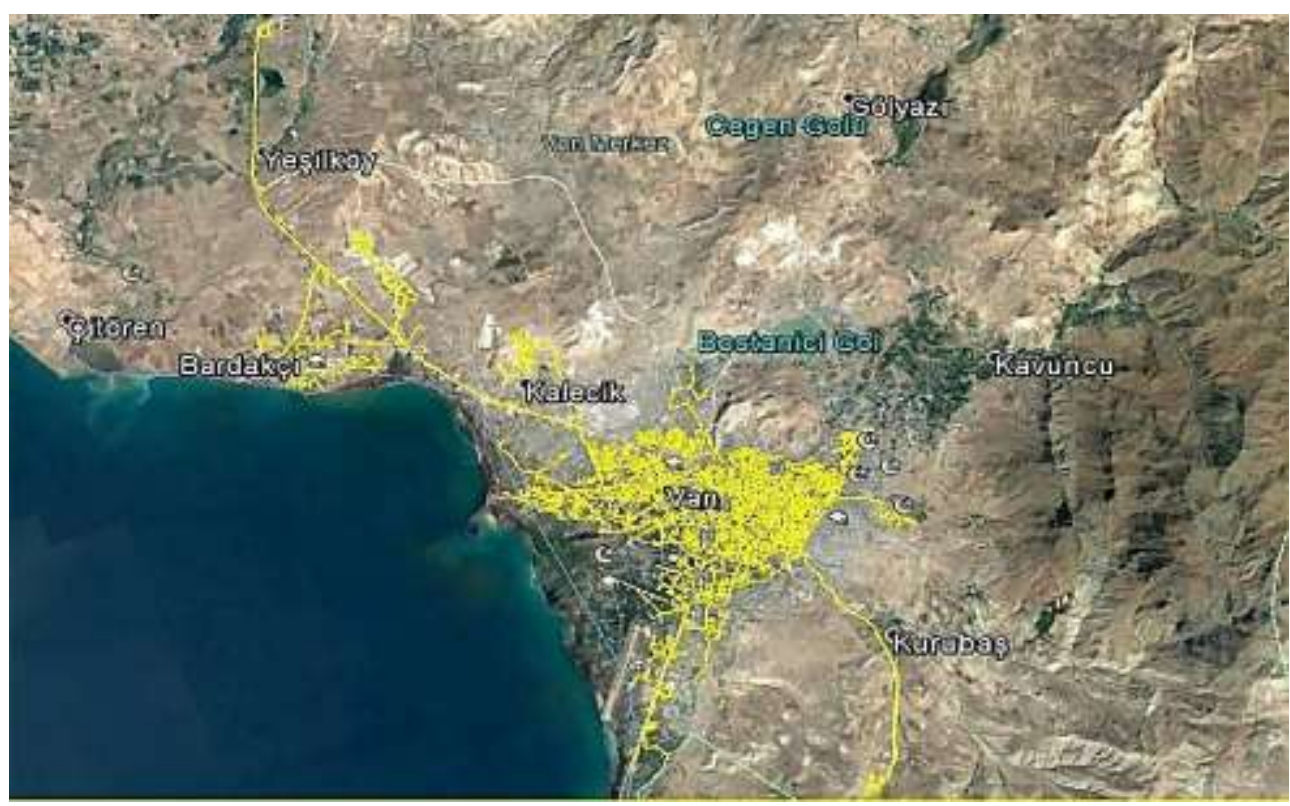

Şekil 5. Van mevcut doğal gaz hattı haritası [12]

\section{Sonuç ve Öneriler}

Kentte hava kalitesi üzerinde 1sınma ve motorlu araçlar etkindir. Motorlu araçlardan kaynaklı kirliliğinin hava kalitesi üstündeki etkisi yıl içinde anlamlı derecede değişmese de 1sınma kaynaklı kirliliğinin etkisi kış ve yaz mevsimlerinde çok farklılık göstermektedir. Hava kalite tesisinin aylık verilerinden görüldüğü gibi kirlilik verileri kış mevsiminde artış göstermektedir. Bu durumun nedeni şüphesiz ki isınmadan kaynaklıdır. Bu durumun temel nedenleri; kaliteli olmayan katı yakıt kullanımı, doğal gaz hattının şehrin her yerine ulaşamaması, hattın ulaştığı yerlerde halkın katı yakıt kullanma 1srarı, konutların ve diğer yapıların isı yalıtımsız olması, yanlış yakma tekniklerinin kullanılması (eksik yanma vb.) ve baca temizliğinin periyodik yapılmamasıdır. Kentteki hava kalitesi ölçüm tesisinden edinilen değerler 1şı̆̆ında hava kalitesi iyi düzeydedir. Ölçülen $\mathrm{SO}_{2}$ değerleri limit değerlerin atında kalırken, $\mathrm{PM}_{10}$ konsantrasyonları kış döneminde birkaç defa limit değerleri aşmıştır. Kentte bulunan sayıca az olan endüstri kuruluşunun, hava kalitesi üstündeki olumsuz etkisi, yapılan kontrol ve denetimlerle ilgili mevzuattaki emisyon limit değerlerinin altında tutulmaya çalışılmıştır. 2007 y1lı itibari ile evsel ısınmada ve sanayide kullanılmak üzere doğal gazın aktif olması ile birlikte bilhassa $\mathrm{SO}_{2}$ konsantrasyonlarında kayda değer azalma gözlenmiştir. Avrupa, WHO ve ABD limit değerlerinin üstünde seyreden $\mathrm{SO}_{2}$ konsantrasyonları yakıt politikasındaki değişmeyle beraber $\mathrm{WHO}$ ve $\mathrm{ABD}$ değerlerinin altına inmiştir. Bu sebeple kentin doğal gaz ulaşmayan ilçelerine de hat sağlanması ile tehlikesiz ve temiz bir yakıt olarak kabul görülen doğal gazın kullanılmasının yaygınlaştırılması gerekmektedir. Ayrıca hattın ulaşmadığı noktalarda kalitesiz yakıt konusunda kontroller satış noktalarından başlayıp kullanıcılar bilgilendirilmeli ve zararları izah edilmelidir.

\section{Kaynaklar}

[1] Sirmen L. 1990. Çevre Kanunu'na Göre Çevrenin Kirletilmesinden Doğan Sorumluluk. Ankara Barosu Dergisi, 1: 22-30.

[2] Bozlağan R. 2005. Sürdürülebilir Gelişme Düşüncesinin Tarihsel Arka Planı. Sosyal Siyaset Konferanslar1 Dergisi, 50: 1011-1028.

[3] Bayram T., Erkuş A., Öztürk D. 2014. Türkiye'de Su Kaynaklarının Dünü, Bugünü ve Geleceği. Yüzüncü Y1l Üniversitesi Fen Bilimleri Enstitüsü Dergisi, 19 (1-2): 70-74.

[4] Altıkat A., Ekmekyapar Torun F., Turan Bayram T. 2011. Küresel kirlilik: Dünya, Avrupa Birliği ve Türkiye'de Hava Kirliliği Örneği. Erciyes Üniversitesi Fen Bilimleri Enstitüsü Fen Bilimleri Dergisi, 27 (2): 134-149. 
[5] Aydınlar B., Güven H., Kirksekiz S. 2009. Hava Kirliliği Nedir, Ölçüm ve Hava Kalite Modelleme Yöntemleri Nelerdir. Sakarya Üniversitesi Fen Bilimleri Enstitüsü Çevre Mühendisliği Bölümü, Hava Kirliliği ve Modellemesi Dergisi,16 (2): 83-91.

[6] Yazıcı H., Yusuf Ç.A.Y., Sekmen Y. 2010. Hava Kirliliğinin Doğal Gaz Kullanımı İle Değişimi, Denizli İli Örneği. Selçuk Teknik Dergisi, 9 (3): 205-215.

[7] Demirarslan K.O., Akınc1 H. 2018. CBS ve Hava Kalitesi Verileri Kullanılarak Marmara Bölgesinin Kış Sezonunda Hava Kalitesinin Değerlendirilmesi. Doğal Afetler ve Çevre Dergisi, 4 (1): 11-27.

[8] Eren Z., Turan T. 2007. Doğal Gaza Geçiş ile Birlikte Erzurum İlinde Fosil Yakıtlardan Kaynaklanan Hava Kirliliğindeki Değişim. Türkiye Çevre Müh. Odası, 7.

[9] Bolu F., Zoroğlu G., Mayda A.S. 2015. Düzce Hava Kalitesi İzleme İstasyonu 2014 Yılı Verilerinin Saatlik, Günlük ve Mevsimsel Değişimlerinin İncelenmesi. TAF Preventive Medicine Bulletin, 14 (5): 387-393.

[10] Toros H., Erdun H., Çapraz Ö., Özer B., Daylan E.B., Öztürk A.İ. 2013. Air Pollution and Quality Levels in Metropolitans of Turkey for Sustainable life. EJOSAT: European Journal of Science and Technology, 1 (1): 12-18.

[11] Cetin M., Kalayci Onac A., Sevik H., Sen B. 2018. Temporal and Regional Change of Some Air Pollution Parameters in Bursa, Air Quality. Atmosphere \& Health, 1-6.

[12] Çevre ve Şehircilik İl Müdürlüğü, 2017. Van İli 2016 Yılı Çevre Durum Raporu. Çevre Yönetimi ve Denetimi Şube Müdürlüğ̈̈, Van.

[13] Doğalgaz Piyasası 2016 Y1lı Sektör Raporu, 2017. Enerji Piyasası Düzenleme Kurumu, Strateji Geliştirme Dairesi Başkanlığı, Ankara.

[14] Kalkınma Bakanlığı, 2013. İllerin ve Bölgelerin Sosyo-Ekonomik Gelişmişlik Sıralaması Araştırması (SEGE-2011). Bölgesel Gelişme ve Yapısal Uyum Genel Müdürlüğ̈̈, Ankara.

[15] Van'ın Sanayi Envanterinin Oluşturulması Fizibilite Çalışması, 2015. Bilim Sanayi ve Teknoloji Bakanlığı Van İl Müdürlüğü, Van.

[16] Orman ve Su İşleri Bakanlığı, Meteoroloji Genel Müdürlüğü, 2016. 2016 Y11ı Şubat Ayı Sıcaklık Değerlendirmesi. Araştırma Dairesi Başkanlığı Klimatoloji Şube Müdürlügüü Hidrometeoroloji Şube Müdürlüğ̈̈, Ankara.

[17] http://www.havaizleme.gov.tr/Default.ltr.aspx (Erişim Tarihi: 31.12.2016)

[18] Hava Kalitesi Değerlendirme ve Yönetimi Yönetmeliği, 2008. Resmi Gazete, Sayı: 26898. 